\title{
Article
}

\section{The Impact of the FKBP5 Gene Polymorphisms on the Relationship between Traumatic Life Events and Psychotic-Like Experiences in Non-Clinical Adults}

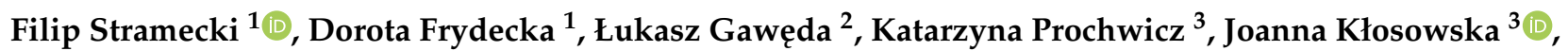 \\ Jerzy Samochowiec ${ }^{4}{ }^{\circ}$, Krzysztof Szczygieł $^{4}$, Edyta Pawlak ${ }^{5}{ }^{\circledR}$, Elżbieta Szmida ${ }^{6}{ }^{\oplus}$, Paweł Skiba ${ }^{6}$, \\ Andrzej Cechnicki ${ }^{7}$ and Błażej Misiak ${ }^{1, *(1)}$
}

check for

updates

Citation: Stramecki, F.; Frydecka, D.;

Gawęda, Ł.; Prochwicz, K.;

Kłosowska, J.; Samochowiec, J.;

Szczygieł, K.; Pawlak, E.; Szmida, E.; Skiba, P.; et al. The Impact of the FKBP5 Gene Polymorphisms on the Relationship between Traumatic Life Events and Psychotic-Like

Experiences in Non-Clinical Adults. Brain Sci. 2021, 11, 561. https:// doi.org/10.3390/brainsci11050561

Academic Editors: Javier Labad, Alexandre González-Rodríguez and Virginia Soria

Received: 13 April 2021

Accepted: 24 April 2021

Published: 28 April 2021

Publisher's Note: MDPI stays neutral with regard to jurisdictional claims in published maps and institutional affiliations.

Copyright: (c) 2021 by the authors Licensee MDPI, Basel, Switzerland. This article is an open access article distributed under the terms and conditions of the Creative Commons Attribution (CC BY) license (https:/ / creativecommons.org/licenses/by/ $4.0 /)$.
1 Department of Psychiatry, Wroclaw Medical University, Pasteur Street 10, 50-367 Wroclaw, Poland; fstramecki@gmail.com (F.S.); dfrydecka@gmail.com (D.F.)

2 Clinical Neuroscience Lab, Institute of Psychology, Polish Academy of Sciences, Jaracza Street 1, 00-378 Warsaw, Poland; lgaweda@wum.edu.pl

3 Institute of Psychology, Jagiellonian University, Ingardena 6 Street, 30-060 Krakow, Poland; katarzyna.prochwicz@uj.edu.pl (K.P.); joanna.klosowska@uj.edu.pl (J.K.)

4 Department of Psychiatry, Pomeranian Medical University, Broniewskiego 26 Street, 71-457 Szczecin, Poland; samoj@pum.edu.pl (J.S.); kf.szczygiel@gmail.com (K.S.)

5 Department of Experimental Therapy, Hirszfeld Institute of Immunology and Experimental Therapy, Polish Academy of Sciences, Weigla Street 12, 53-114 Wroclaw, Poland; edyta.pawlak@hirszfeld.pl

6 Department of Genetics, Wroclaw Medical University, Marcinkowskiego 1 Street, 50-368 Wroclaw, Poland; e.szmida@gmail.com (E.S.); pawel.skiba@umed.wroc.pl (P.S.)

7 Department of Community Psychiatry, Medical College Jagiellonian University, Sikorskiego Place 2, 31-115 Krakow, Poland; acechnicki@interia.pl

* Correspondence: blazej.misiak@umed.wroc.pl

Abstract: Common variations of the FKBP5 gene are implicated in psychotic disorders, by modulating the hypothalamic-pituitary-adrenal axis reactivity to stress. It has been demonstrated that some of them might moderate the effects of childhood trauma on psychosis proneness. However, these associations have not been investigated with respect to traumatic life events (TLEs). Therefore, we aimed to explore whether the FKBP5 polymorphisms moderate the effects of TLEs on the level of psychotic-like experiences (PLEs). A total of 535 non-clinical adults were approached for participation, and genotyping of six FKBP5 polymorphisms (rs3800373, rs9470080, rs4713902, rs737054, rs1360780 and rs9296158) was performed. The Prodromal Questionnaire-16 (PQ-16) and the Traumatic Events Checklist (TEC) were administered to assess PLEs and TLEs, respectively. Among the rs1360780 CC homozygotes, a history of physical abuse was associated with significantly higher PQ-16 scores. This difference was not significant in the rs1360780 T allele carriers. Similarly, a history of physical abuse was associated with significantly higher PQ-16 scores in the rs9296158 GG homozygotes but not in the rs9296158 A allele carriers. Finally, emotional neglect was related to significantly higher PQ-16 scores in the rs737054 T allele carriers but not in the rs737054 CC homozygotes. The present study indicates that variation in the FKBP5 gene might moderate the effects of lifetime traumatic events on psychosis proneness.

Keywords: schizophrenia; genetics; cortisol; HPA axis

\section{Introduction}

In recent years, a growing body of studies focus on the role of gene-environment interactions in the development of numerous mental disorders, including schizophrenia [1]. Traumatic life events (TLEs) have been considered a significant risk factor for the development of psychosis [2] and cognitive impairments in patients with schizophrenia [3], as well as cognitive biases [4] and psychotic-like experiences (PLEs) in non-clinical subjects [5,6]. Moreover, TLEs play a pivotal role in the pathophysiology of various mental disorders, 
including schizophrenia $[2,3,7]$. Although it has been reported that childhood traumatic experiences may lead to the development of psychosis [8], it has also been observed that cumulative lifetime trauma exposure has a significant influence on a risk of psychosis [9].

Notably, PLEs are considered one of the phenomena that lie on the continuum of psychosis, where non-clinical psychotic symptoms precede the onset of overt psychosis [10]. These experiences include bizarre experiences, perceptual abnormalities (e.g., hearing unusual sounds such as clicking, humming or ringing) and delusional-like ideas (e.g., persecutory ideations or magical thinking) that range from perceptual illusions to subclinical attenuated positive symptoms [5]. During the past two decades, the body of research on PLEs has systematically grown [11-14]. It was repeatedly reported that PLEs are common in the general population [15-18] and are often not associated with severe distress or a lack of insight [16]. The recent cross-national analysis based on more than 31,000 respondents in 18 counties estimated the prevalence rate of PLEs at 7.2\% [19]. Moreover, it has been reported that individuals exposed to childhood trauma (especially emotional or sexual abuse) are more likely to experience PLEs [20]. Moreover, early life traumatic experiences increase the prevalence of PLEs in young adults [21], some of whom may even experience frequent hallucinatory and delusional experiences [22].

Exposure to acute and/or chronic stress alters proper functioning of the main stress hormone system - the hypothalamic-pituitary-adrenal (HPA) axis [23,24], and activates a cascade of biological interactions that increase a risk of psychosis $[25,26]$. The HPA axis response can be modulated by the FK-506 binding protein 5, encoded by the FKBP5 gene located on the chromosome 6p21 [27]. The FKBP5 is a co-chaperone of the heat shock protein hsp90, which modulates the glucocorticoid receptor (GR) sensitivity to the main stress hormone-cortisol [27]. The interaction of the FKBP5 protein with the GR leads to decreased receptor affinity and entails suppressed nuclear translocation $[28,29]$. This interaction indicates that stress exposure, by causing an increase in the cortisol level, leads to up-regulated FKBP5 expression and reduced GR activity [27]. It has been shown that patients with psychosis present increased expression of $F K B P 5$ mRNA in the dorsolateral prefrontal cortex [30] and the hippocampus [31] when compared to healthy controls. Hence, altered expression of the FKBP5 gene may be correlated with the HPA axis dysregulation. It has been shown that patients with schizophrenia [32] and first-episode psychosis [33] present elevated blood levels of circulating cortisol when compared to healthy controls. Moreover, the cortisol awakening response in patients with schizophrenia is significantly flattened when compared to healthy controls [34]. Meta-analysis investigating the HPA axis response to experimental social stress revealed that patients with psychosis have lower cortisol levels both in anticipation and after exposure to social stress [35]. It has also been observed that individuals at ultra-high risk of psychosis present significantly higher salivary cortisol levels than healthy controls [36].

In the past two decades, numerous studies have focused on genetic polymorphisms and epigenetic modifications that may influence the HPA axis reactivity to stress [37]. It has previously been reported that four single nucleotide polymorphisms (SNPs), including rs1360780, rs3800373, rs9296158 and rs9470080, are associated with decreased sensitivity of GR to circulating cortisol, leading to diminished negative feedback of the HPA axis $[38,39]$. The FKBP5 gene contains several polymorphic sites that may affect stress response, and thus a risk of psychosis [39]. It has been reported that specific SNPs of the FKBP5 gene may have an impact on the severity of psychotic symptoms in patients with psychosis after adjustment for exposure to TLEs [38,39]. Indeed, the study by Mihaljevic et al. [39] revealed that the rs $3800373 \mathrm{G}$ allele carriers had presented a higher risk of schizophrenia after accounting for childhood trauma exposure than the TT homozygotes. However, individual SNPs of the FKBP5 gene may also play a role in the development of PLEs in a non-clinical population [40-42]. Accordingly, the rs13860780 $\mathrm{T}$ allele carriers have been shown to present higher levels of positive and negative PLEs after exposure to childhood abuse [43,44]. A similar relationship was observed for the rs92961558 polymorphism in non-clinical young adults exposed to bullying in childhood, where the A allele was 
positively correlated with the level of PLEs [45]. It has been observed that the rs3800373 C allele carries exposed to trauma present decreased anxiety sensitivity [46]. Moreover, the rs4713902 C allele carries have been found to show higher baseline cortisol level than the rs4713902 TT homozygotes [47]. In turn, the rs737054 polymorphism is located within a highly conserved region of the FKBP5 intron 5 that has high regulatory potential $[48,49]$.

So far, studies investigating interactions of the FKBP5 gene with stress exposure in individuals with psychosis and PLEs have mostly focused on childhood trauma experience $[41,45,46,50]$. Therefore, in this study we aimed to investigate the influence of the FKBP5 gene polymorphisms on the association between the level of PLEs and lifetime exposure to stress.

\section{Materials and Methods}

\subsection{Participants}

The sample included 535 individuals aged 18 to 30 ( $23.4 \pm 3.0$ years) recruited from university students of various faculties (computer science, mathematics, medicine, nursing, pedagogy and psychology) from three big cities in Poland (Krakow, Wroclaw, and Szczecin). All participants represented Caucasian ethnicity and were non-consanguineous. A history of clinical diagnosis was provided with a self-report questionnaire designed for the study. The Ethics Committee at Wroclaw Medical University (Wroclaw, Poland) approved the study protocol, and all participants gave written informed consent (project number: STM C230.018.34; approval number: 254/2018; issued on 19 July 2018).

\subsection{Measures}

\subsubsection{The Traumatic Events Checklist (TEC)}

The TEC was used to assess a history of TLEs [51]. It is a self-report questionnaire that consists of 29 items. To measure emotional neglect (EN) we used the item: "When you were a child or a teenager have you ever felt emotionally neglected (e.g., being left alone, insufficient affection) by your parents, brothers or sisters?". Emotional abuse (EA) was assessed with the use of the item: "When you were a child or a teenager have you ever felt emotionally abused (e.g., being belittled, teased, called names, threatened verbally, or unjustly punished) by your parents, brothers or sisters?". Physical abuse (PA) and bullying was evaluated with the item: "When you were a child or teenager, did you experience physical abuse (e.g., tormenting, beating, psychically hurting) from your parents, brothers or sisters or peers?". Sexual abuse (SA) was measured with the item: "When you were a child or a teenager have you ever been sexually harassed or abused by your parents, brothers or sisters or strangers?".

\subsubsection{The Prodromal Questionnaire 16 (PQ-16)}

The PQ-16 is a 16-item self-report questionnaire screening for psychosis risk and the presence of PLEs [52]. It consists of items assessing experiences of positive symptoms (nine items investigating perceptual aberrations as well as five items screening for delusional ideation, unusual thought content and paranoia) and two items focusing on negative symptoms. The original questionnaire consists of two scales, where the first investigates PLEs presence by "present" and "non-present"; the second measures associated emotional distress by a four-point Likert scale. We used the Polish version of PQ-16, which was developed with the use of a back-translocation procedure and also was used in our previous studies [53]. In the present study, the level of distress associated with experiencing PLEs, further referred to as the PQ-16 score, was used as the outcome variable. Considering that perceptual abnormalities and delusional ideas are the first anomalies that can lead to psychosis development, we excluded items " 1 " and "7", which investigate negative symptoms. 


\subsection{Genotyping}

In the present study, we selected six SNPs (rs3800373, rs9470080, rs4713902, rs737054, rs1360780 and rs9296158) based on their functional impact on the FKBP5 gene and the HPA axis activity. DNA samples were obtained using buccal swabs and the prepIT $\bullet$ L2P kit (DNA Genotek, Ottawa, ON, Canada). Although blood is usually collected to obtain DNA (it provides not only nucleated cells containing DNA but also many other physiological factors contained in plasma), the alternative, noninvasive sampling methods based on cheek-cell collection (oral or buccal epithelial cells collected with swabs, brushes or mouthwashes) are recommended in cases of large, population-based and multicentric studies [54]. Preference of buccal cells to obtain DNA is also related to unavailability of medical staff required to collect blood, and provides sufficient DNA quantity and quality. It should also be noted that buccal swabs are less contaminated by proteins compared to other methods of collecting oral biological material, and thus they enable improved quality and quantity of DNA $[54,55]$. Six common SNPs of the FKBP5 gene (rs3800373, rs9470080, rs4713902, rs737054, rs1360780 and rs9296158) were genotyped with the allelic discrimination technique using validated and predesigned TaqMan ${ }^{\circledR}$ SNP Genotyping Assays (C_27489960_10, C___92160_10, C_30559929_10, C__1256778_10, C__8852038_10, and C__1256775_30, respectively) according to the manufacturer's instructions (ThermoFisher Scientific Inc., Waltham, MA, U.S.). In accordance with current recommendations for buccal cell collection, we decided to perform genotyping in duplicates for $25 \%$ of randomly selected samples to control for genotyping accuracy [56,57]; we decided to control our results $(25 \%$ of randomly chosen samples from both groups) to check for genotyping accuracy. The results were controlled ( $25 \%$ of randomly chosen samples from both groups) to check for genotyping accuracy. Identical genotypes were identified in all duplicates. Subjects involved in genotyping were blinded to ID of participants and the data collected by specific questionnaires used in this study.

\subsection{Statistics}

The $\chi^{2}$ test was used to assess whether the distribution of genotypes followed the Hardy-Weinberg equilibrium (HWE). Bivariate comparisons were performed using the Mann-Whitney U test. The analysis of covariance (ANCOVA) was performed to test the effects of specific TLEs, SNPs and interactions between TLEs and SNPs on the PQ-16 score. Age and gender were added as the covariates. Separate models for specific SNPs and TLEs were tested. Post hoc comparisons were performed using the Games-Howell test in case of significant two-way interactions. Due to multiple testing, the Benjamini-Hochberg correction with the false discovery rate of $25 \%$ was applied. After this correction, results of all tests were considered significant if the $p$-value was less $\leq 0.022$.

\section{Results}

Main characteristics of all participants are presented in Table 1. Out of 535 individuals approached for participation, 461 individuals provided data on a history of TLEs and the level of PQ-16 (86.2\%). Sufficient quality of DNA was obtained for 441-449 participants (82.4-83.9\%). Rates of EN, EA, PA and SA were as follows: $34.1 \%, 41.4 \%, 15.4 \%$, and $8.2 \%$ participants, respectively. As expected, a history of all categories of TLEs was associated with significantly higher PQ-16 scores (Table 2). Clinical diagnosis (mood and anxiety disorders) was reported by $8.2 \%$ of the sample. None of these participants reported being diagnosed with psychotic disorders.

Main and interactive effects of the FKBP5 SNPs on the PQ-16 score are shown in Table 3. There were significant effects of interactions between PA and two FKBP5 SNPs (rs1360780 and rs9296158) on the PQ-16 score. Similarly, the interaction between EN and the rs737054 polymorphism was significantly associated with the PQ-16 score. In the majority of models, significant main effects of age and TLEs were found. In two models, main effects of the rs3800373 (the model with EA) and the rs9296158 (the model with PA) were observed. 
Table 1. General characteristics of the sample.

\begin{tabular}{|c|c|c|}
\hline & $n$ & Mean \pm SD or $n(\%)$ \\
\hline Age, years & 461 & $23.4 \pm 3.0$ \\
\hline Gender, M/F & 460 & $133 / 327(40.7 / 59.3)$ \\
\hline Clinical diagnosis & 461 & $38(8.2)$ \\
\hline $\mathrm{EN}$ & 461 & $157(34.1)$ \\
\hline EA & 461 & $191(41.4)$ \\
\hline PA & 461 & $71(15.4)$ \\
\hline SA & 461 & $38(8.2)$ \\
\hline PQ-16 & 461 & $4.1 \pm 4.6$ \\
\hline rs1360780 & 444 & \\
\hline $\mathrm{CC}$ & & $260(58.56)$ \\
\hline $\mathrm{CT}$ & & $159(3.46)$ \\
\hline $\mathrm{TT}$ & & $31(6.98)$ \\
\hline rs9296158 & 445 & \\
\hline AA & & $26(5.84)$ \\
\hline $\mathrm{AG}$ & & $159(35.73)$ \\
\hline GG & & $260(58.43)$ \\
\hline rs3800373 & 443 & \\
\hline GG & & $37(8.35)$ \\
\hline TG & & $144(32.51)$ \\
\hline $\mathrm{TT}$ & & $262(59.14)$ \\
\hline rs9470080 & 443 & \\
\hline $\mathrm{CC}$ & & $245(55.30)$ \\
\hline $\mathrm{CT}$ & & $151(34.09)$ \\
\hline $\mathrm{TT}$ & & 47 (10.61) \\
\hline rs4713902 & 441 & \\
\hline $\mathrm{CC}$ & & $50(11.34)$ \\
\hline $\mathrm{CT}$ & & 154 (34.92) \\
\hline TT & & $237(53.74)$ \\
\hline rs737054 & 449 & \\
\hline $\mathrm{CC}$ & & $224(49.89)$ \\
\hline $\mathrm{CT}$ & & $182(40.53)$ \\
\hline $\mathrm{TT}$ & & $43(9.58)$ \\
\hline
\end{tabular}

Abbreviations: TEC, Traumatic Events Checklist; EN, emotional neglect; EA, emotional abuse; PA, physical abuse; SA, sexual abuse; PQ-16, the Prodromal Questionnaire 16.

Table 2. The PQ-16 score with respect to a history of TLEs.

\begin{tabular}{cccc}
\hline & TLEs (+) & TLEs (-) & $p$ \\
\hline EA & $5.10 \pm 5.25$ & $3.41 \pm 3.81$ & $<0.001$ \\
\hline EN & $5.25 \pm 5.46$ & $3.52 \pm 3.91$ & $<0.001$ \\
\hline PA & $5.24 \pm 5.69$ & $3.90 \pm 4.30$ & 0.022 \\
\hline SA & $7.10 \pm 6.76$ & $3.83 \pm 4.22$ & $<0.001$
\end{tabular}

Abbreviations: TLEs(+), positive history of traumatic life events; TLEs(-), negative history of traumatic life events, EN, emotional neglect; EA, emotional abuse; PA, physical abuse; SA, sexual abuse. 
Table 3. Main and interactive effects of the FKBP5 variants on the PQ-16 score.

\begin{tabular}{|c|c|c|c|c|c|c|c|}
\hline TLEs & IV or Covariate & rs1360780 & rs9296158 & rs3800373 & rs9470080 & rs4713902 & rs737054 \\
\hline \multirow{6}{*}{ EN } & Age & $\begin{array}{l}F=48.00 \\
p<0.001\end{array}$ & $\begin{array}{l}F=47.28 \\
p<0.001\end{array}$ & $\begin{array}{l}F=43.37 \\
p<0.001\end{array}$ & $\begin{array}{l}F=42.87 \\
p<0.001\end{array}$ & $\begin{array}{l}F=41.92 \\
p<0.001\end{array}$ & $\begin{array}{l}F=45.36, \\
p<0.001\end{array}$ \\
\hline & Gender & $\begin{array}{l}F=1.62 \\
p=0.204\end{array}$ & $\begin{array}{l}F=1.67 \\
p=0.197\end{array}$ & $\begin{array}{l}F=1.59 \\
p=0.208\end{array}$ & $\begin{array}{l}F=1.76 \\
p=0.186\end{array}$ & $\begin{array}{l}F=1.55 \\
p=0.214\end{array}$ & $\begin{array}{l}F=2.20 \\
p=0.139\end{array}$ \\
\hline & TLEs & $\begin{array}{l}F=15.48 \\
p<0.001\end{array}$ & $\begin{array}{l}F=14.54 \\
p<0.001\end{array}$ & $\begin{array}{l}F=1.60 \\
p=0.207\end{array}$ & $\begin{array}{l}F=0.33 \\
p=0.564\end{array}$ & $\begin{array}{l}F=16.48 \\
p<0.001\end{array}$ & $\begin{array}{l}F=17.54, \\
p<0.001\end{array}$ \\
\hline & FKBP5 & $\begin{array}{l}F=1.15 \\
p=0.285\end{array}$ & $\begin{array}{l}F=1.96 \\
p=0.162\end{array}$ & $\begin{array}{l}F=3.24 \\
p=0.073\end{array}$ & $\begin{array}{c}F=1.07 \\
p=0.301\end{array}$ & $\begin{array}{l}F=0.24 \\
p=0.627\end{array}$ & $\begin{array}{l}F=0.19 \\
p=0.660\end{array}$ \\
\hline & FKBP5 $\times$ TLEs & $\begin{array}{l}F=1.04 \\
p=0.309\end{array}$ & $\begin{array}{l}F=1.21 \\
p=0.273\end{array}$ & $\begin{array}{l}F=1.43 \\
p=0.232\end{array}$ & $\begin{array}{l}F=5.35 \\
p=0.21\end{array}$ & $\begin{array}{c}F=2.45 \\
p=0.118\end{array}$ & $\begin{array}{l}F=7.84 \\
p=0.005\end{array}$ \\
\hline & $\mathrm{R}^{2}$ & 0.142 & 0.141 & 0.150 & 0.144 & 0.134 & 0.141 \\
\hline \multirow{6}{*}{ EA } & Age & $\begin{array}{l}F=48.84 \\
p<0.001\end{array}$ & $\begin{array}{l}F=47.94 \\
p<0.001\end{array}$ & $\begin{array}{l}F=43.58 \\
p<0.001\end{array}$ & $\begin{array}{l}F=42.56 \\
p<0.001\end{array}$ & $\begin{array}{l}F=44.25 \\
p<0.001\end{array}$ & $\begin{array}{l}F=45.82 \\
p<0.001\end{array}$ \\
\hline & Gender & $\begin{array}{l}F=2.48 \\
p=0.116\end{array}$ & $\begin{array}{l}F=2.53 \\
p=0.112\end{array}$ & $\begin{array}{l}F=2.20 \\
p=0.139\end{array}$ & $\begin{array}{l}F=2.14 \\
p=0.145\end{array}$ & $\begin{array}{l}F=2.22 \\
p=0.137\end{array}$ & $\begin{array}{l}F=2.67 \\
p=0.103\end{array}$ \\
\hline & TLEs & $\begin{array}{l}F=20.13 \\
p<0.001\end{array}$ & $\begin{array}{l}F=19.35 \\
p<0.001\end{array}$ & $\begin{array}{l}F=2.55 \\
p=0.111\end{array}$ & $\begin{array}{l}F=2.50 \\
p=0.115\end{array}$ & $\begin{array}{l}F=19.79 \\
p<0.001\end{array}$ & $\begin{array}{l}F=19.57 \\
p<0.001\end{array}$ \\
\hline & FKBP5 & $\begin{array}{l}F=0.10 \\
p=0.747\end{array}$ & $\begin{array}{l}F=0.48 \\
p=0.491\end{array}$ & $\begin{array}{l}F=4.64 \\
p=0.032\end{array}$ & $\begin{array}{l}F=2.45 \\
p=0.119\end{array}$ & $\begin{array}{l}F=1.89 \\
p=0.170\end{array}$ & $\begin{array}{l}F=0.67 \\
p=0.414\end{array}$ \\
\hline & FKBP5 × TLEs & $\begin{array}{l}F=0.12 \\
p=0.731\end{array}$ & $\begin{array}{l}F=0.06 \\
p=0.815\end{array}$ & $\begin{array}{l}F=1.12 \\
p=0.290\end{array}$ & $\begin{array}{l}F=2.18 \\
p=0.141\end{array}$ & $\begin{array}{c}F=0.11 \\
p=0.739\end{array}$ & $\begin{array}{l}F=0.832 \\
p=0.362\end{array}$ \\
\hline & $R^{2}$ & 0.147 & 0.145 & 0.155 & 0.147 & 0.138 & 0.143 \\
\hline \multirow{6}{*}{ PA } & Age & $\begin{array}{l}F=49.06 \\
p<0.001\end{array}$ & $\begin{array}{l}F=48.56 \\
p<0.001\end{array}$ & $\begin{array}{l}F=42.46 \\
p<0.001\end{array}$ & $\begin{array}{l}F=41.35 \\
p<0.001\end{array}$ & $\begin{array}{l}F=41.52 \\
p<0.001\end{array}$ & $\begin{array}{l}F=45.54, \\
p<0.001\end{array}$ \\
\hline & Gender & $\begin{array}{l}F=4.43 \\
p=0.038\end{array}$ & $\begin{array}{l}F=4.07 \\
p=0.044\end{array}$ & $\begin{array}{l}F=3.59 \\
p=0.059\end{array}$ & $\begin{array}{l}F=3.33 \\
p=0.069\end{array}$ & $\begin{array}{c}F=3.15 \\
p=0.077\end{array}$ & $\begin{array}{l}F=3.79 \\
p=0.052\end{array}$ \\
\hline & TLEs & $\begin{array}{l}F=8.87 \\
p=0.003\end{array}$ & $\begin{array}{l}F=7.44 \\
p=0.007\end{array}$ & $\begin{array}{l}F=1.83 \\
p=0.177\end{array}$ & $\begin{array}{l}F=2.17 \\
p=0.142\end{array}$ & $\begin{array}{l}F=5.78 \\
p=0.017\end{array}$ & $\begin{array}{l}F=8.305, \\
p=0.004\end{array}$ \\
\hline & FKBP5 & $\begin{array}{l}F=4.12 \\
p=0.43\end{array}$ & $\begin{array}{l}F=5.90 \\
p=0.016\end{array}$ & $\begin{array}{l}F=1.95 \\
p=0.164\end{array}$ & $\begin{array}{l}F=1.23 \\
p=0.269\end{array}$ & $\begin{array}{l}F=0.90 \\
p=0.343\end{array}$ & $\begin{array}{l}F=0.12 \\
p=0.729\end{array}$ \\
\hline & FKBP5 $\times$ TLEs & $\begin{array}{l}F=5.53 \\
p=0.019\end{array}$ & $\begin{array}{l}F=6.80 \\
p=0.009\end{array}$ & $\begin{array}{l}F=0.10 \\
p=0.752\end{array}$ & $\begin{array}{l}F=0.01 \\
p=0.925\end{array}$ & $\begin{array}{l}F=0.00 \\
p=0.927\end{array}$ & $\begin{array}{l}F=1.88 \\
p=0.171\end{array}$ \\
\hline & $\mathrm{R}^{2}$ & 0.141 & 0.141 & 0.131 & 0.121 & 0.111 & 0.125 \\
\hline \multirow{6}{*}{ SA } & Age & $\begin{array}{l}F=45.09 \\
p<0.001\end{array}$ & $\begin{array}{l}F=44.19 \\
p<0.001\end{array}$ & $\begin{array}{l}F=39.66 \\
p<0.001\end{array}$ & $\begin{array}{l}F=39.19 \\
p<0.001\end{array}$ & $\begin{array}{l}F=40.52 \\
p<0.001\end{array}$ & $\begin{array}{l}F=42.56 \\
p<0.001\end{array}$ \\
\hline & Gender & $\begin{array}{l}F=1.33 \\
p=0.250\end{array}$ & $\begin{array}{l}F=1.42 \\
p=0.235\end{array}$ & $\begin{array}{l}F=1.31 \\
p=0.252\end{array}$ & $\begin{array}{l}F=1.35 \\
p=0.245\end{array}$ & $\begin{array}{l}F=1.38 \\
p=0.242\end{array}$ & $\begin{array}{l}F=1.57 \\
p=0.211\end{array}$ \\
\hline & TLEs & $\begin{array}{l}F=16.78 \\
p<0.001\end{array}$ & $\begin{array}{l}F=15.05 \\
p<0.001\end{array}$ & $\begin{array}{l}F=5.95 \\
p=0.015\end{array}$ & $\begin{array}{l}F=6.70 \\
p=0.010\end{array}$ & $\begin{array}{l}F=11.50 \\
p=0.001\end{array}$ & $\begin{array}{l}F=17.68, \\
p<0.001\end{array}$ \\
\hline & FKBP5 & $\begin{array}{l}F=1.19 \\
p=0.275\end{array}$ & $\begin{array}{l}F=0.96 \\
p=0.329\end{array}$ & $\begin{array}{l}F=1.05 \\
p=0.305\end{array}$ & $\begin{array}{l}F=1,79 \\
p=0.182\end{array}$ & $\begin{array}{l}F=1.47 \\
p=0.227\end{array}$ & $\begin{array}{l}F=0.18 \\
p=0.671\end{array}$ \\
\hline & FKBP5 $\times$ TLEs & $\begin{array}{l}F=0.93 \\
p=0.337\end{array}$ & $\begin{array}{l}F=0.37 \\
p=0.543\end{array}$ & $\begin{array}{l}F=0.39 \\
p=0.531\end{array}$ & $\begin{array}{l}F=0.19 \\
p=0.732\end{array}$ & $\begin{array}{l}F=0.38 \\
p=0.538\end{array}$ & $\begin{array}{l}F=0.93 \\
p=0.336\end{array}$ \\
\hline & $\mathrm{R}^{2}$ & 0.146 & 0.141 & 0.145 & 0.129 & 0.125 & 0.139 \\
\hline
\end{tabular}

Abbreviations: IV, independent variable; TLEs, traumatic life events; EN—emotional neglect; EA—emotional abuse; PA—physical abuse; SA—sexual abuse, PQ-16—Prodromal Questionnaire 16. 
Results of post hoc analyses are presented in Figure 1. Among the rs1360780 CC homozygotes, a history of PA was associated with significantly higher PQ-16 scores. This difference was not significant in the rs $1360780 \mathrm{~T}$ allele carriers. Similar findings were observed for the rs 9296158 polymorphism. Indeed, a history of PA was associated with significantly higher PQ-16 scores in the rs9296158 GG homozygotes. The rs9296158 GG homozygotes reporting a history of PA had also significantly higher PQ-16 scores in comparison with the rs9296158 A allele carriers without a history of PA. Finally, EN was related to significantly higher PQ-16 scores in the rs737054 $\mathrm{T}$ allele carriers but not in the rs737054 CC homozygotes. The rs737054 T allele carriers had significantly higher PQ-16 scores with a history of EN in comparison with the rs737054 CC homozygotes who did not report EN.
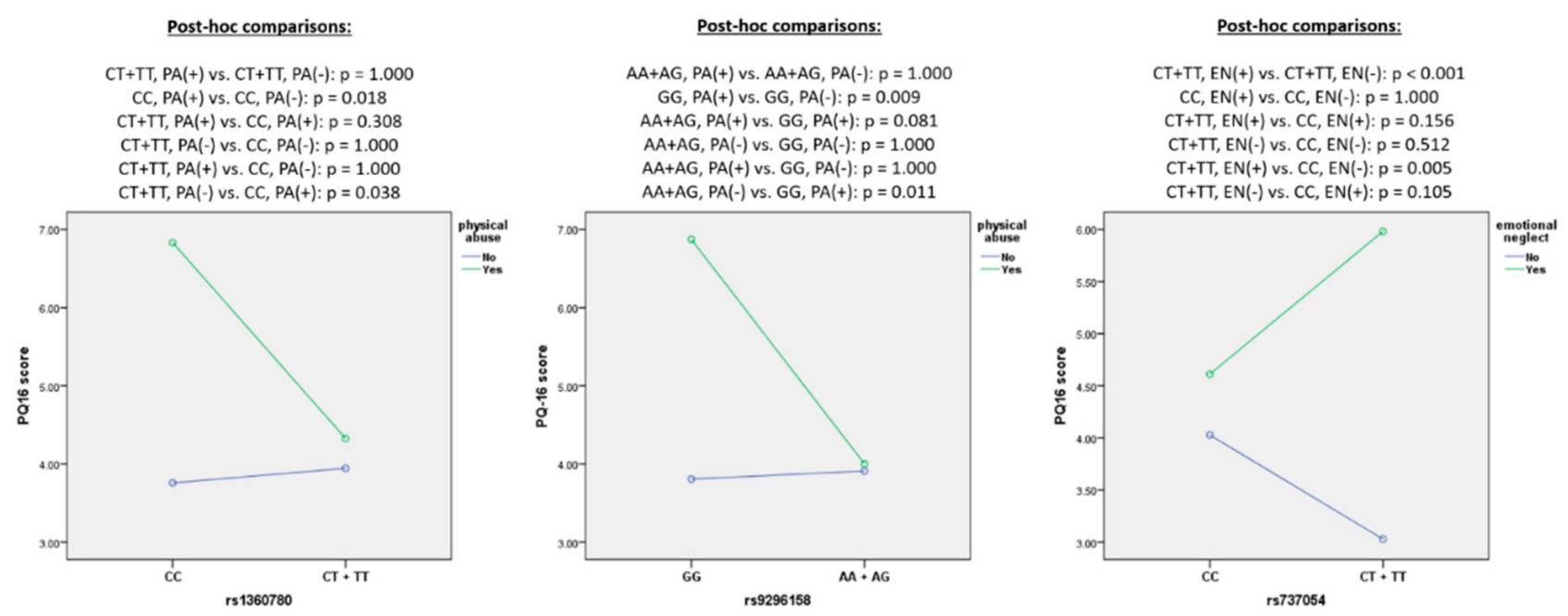

Figure 1. Interactive effects of the FKBP5 genotype and TLEs on the PQ-16 score.

\section{Discussion}

Results of this study support previous findings from studies testing the moderating effects of the FKBP5 gene polymorphisms on the association between trauma exposure and a risk of psychosis or PLEs. More specifically, we found that a history of PA increases a severity of PLEs in the rs1360780 CC and the rs9296158 GG homozygotes. This may be explained by the role of the rs1380780 polymorphism in inducing the FKBP5 gene transcription in response to GR activation [58] followed by stronger cortisol reactivity in response to stress [59] in individuals exposed to trauma carrying the "risk" T allele. Disinhibited induction of the FKBP5 mRNA is responsible for GR resistance and causes diminished negative feedback of the HPA axis, leading to its dysregulation [60]. This stays in line with previous research supporting the role of the rs1360780 and rs9296158 in moderating the effects of childhood trauma on the development of positive PLEs [43-45]. However, these studies have reported that carries of rs1360780 $\mathrm{T}$ allele are more prone to develop psychotic symptoms [44] or greater subclinical psychotic symptoms [49] after exposure to childhood trauma, while we observed the opposite association, where the $\mathrm{C}$ allele was associated with greater severity of PLEs in response to PA. These mixed findings may be associated the fact that previous studies focused only on childhood trauma, while we assessed lifetime TLEs. Interestingly, Yaylac et al. observed that the rs $1380780 \mathrm{C}$ allele carriers and the rs9296158 G allele carriers exposed to childhood maltreatment develop significantly more severe dissociative symptoms when compared to traumatized subjects carrying the rs1380790 $\mathrm{T}$ allele and the rs9296158 A allele, respectively [61]. In turn, dissociation has been associated with the development of overt psychosis and PLEs [62,63]. The study by Mitjans et al. investigated the effect of the FKBP5 gene polymorphisms on treatment outcome in patients with schizophrenia showing that TT homozygotes for the rs13860780 polymorphism have higher risk of non-response to clozapine than the $\mathrm{C}$ allele 
carries [64]. Previous studies have proposed that compound with the ability to interact with FKBP5 could be beneficial in the treatment of stress-related disorders $[57,65,66]$. Taking into account the body of studies supporting the role of FKBP5 in pathophysiology of stressrelated disorders, including schizophrenia, future studies could consider the FKBP5 gene as a potential target for the treatment of psychosis.

The present study also demonstrated that the rs737054 $\mathrm{T}$ allele is associated with a higher severity of PLEs in subjects exposed to EN. The effect of the rs737054 polymorphism on the development of PLEs has not been widely addressed. The only study investigating its role in the development of PLEs in response to childhood trauma failed to find significant associations [39]. Moreover, there are only two studies examining this SNP. One study did not confirm that the rs737054 polymorphism affects susceptibility to borderline personality disorder after considering the role of childhood trauma [67]. In turn, it has been shown that male carries of the T allele at this SNP, exposed to childhood trauma, present significantly greater anxiety sensitivity when compared to the CC homozygotes [46], suggesting the role of the rs737054 polymorphism in stress response by modulating the HPA axis reactivity. Our results suggest that there is an association between variants of the FKBP5, lifetime traumatic events and risk of psychosis. The mechanism of genetic variability influencing psychosis development in response to stress remains unclear. It has also been shown that neurotrophic factors, including the brain-derived neurotrophic factor (BDNF), responsible for neuroplasticity in the human brain, plays a moderating role in the development of psychosis [1,68] and PLEs [69] in individuals exposed to psychosocial stress. Despite multiple observations suggesting that gene-environment interactions may be responsible for individual differences in response to TLEs, further studies are required to understand the exact mechanisms underlying the effects of interactions between genes regulating response to stress and neuroplasticity on the risk of psychosis.

The present study has several methodological limitations that should be taken into consideration when interpreting our findings. In our study, we determined only six variants that may not cover the whole FKBP5 gene. It is likely that genome-wide association studies would provide more comprehensive insight into the effects of variation in the FKBP5 and its interaction with variants in other genes. Some of them did not follow the HWE, suggesting that representativeness of the sample might be limited. Secondly, the proportion of variance in the level of PLEs was also relatively low, suggesting that other factors not recorded by our study might be associated with PLEs. These factors might include familial liability for psychosis, depressive and anxiety symptoms and the level of perceived stress. Third, the data collected from the participants were based on self-reports, which might be characterized by a recall bias. However, reliability of trauma self-reports has been found to be stable over time in patients with psychosis [70]. Another limitation is that our sample had limited size, and independent replication of our findings was not performed. Moreover, this study was based on a non-clinical population, and thus generalization of findings cannot be made. Finally, a cross-sectional design does not allow for making conclusions on causal associations. Nevertheless, it is important to highlight that in contrary to multiple previous studies investigating the role of childhood trauma in the development of psychosis, this study focused also on cumulative lifetime traumatic experiences. To date, the body of studies on adulthood trauma in association with psychosis is very poor. It has previously been reported that TLEs in adulthood may have a different influence on the development of psychosis than childhood trauma. For instance, the study by Liu et al. observed that traumatic events occurring in the adulthood are associated with more severe positive symptoms in patients with schizophrenia, whereas childhood trauma is rather related to more severe depressive symptoms [71].

\section{Conclusions}

The present study indicates that variation in the FKBP5 gene also moderates the effects of lifetime traumatic events on psychosis proneness. These findings provide grounds for developing more personalized approaches in predicting the outcomes of TLEs and 
selecting interventions that aim to restore psychological well-being in this population. However, before their application, larger longitudinal studies that combine results of genetic testing based on high throughput technologies with detailed assessment of complex psychological processes mediating the association between traumatic life events and psychosis are needed.

Author Contributions: Conceptualization, F.S., B.M. and D.F.; formal analysis, B.M., E.P., E.S. and P.S.; investigation, F.S., Ł.G., K.P., J.K., J.S., K.S. and A.C.; methodology, D.F. and B.M.; project administration: D.F., Ł.G., J.S. and A.C.; writing — original draft preparation, F.S.; writing-review and editing, B.M., D.F., E.P. and F.S. All authors have read and agreed to the published version of the manuscript.

Funding: The project is financed from the program of the Minister of Science and Higher Education under the name "Regional Initiative of Excellence" in 2019-2022 project number 002/RID/2018/19 amount of financing 12,000,000 PLN. It was also funded by Wroclaw Medical University, Wroclaw, Poland (grant number: STM C.230.18.034).

Institutional Review Board Statement: The study was conducted according to the guidelines of the Declaration of Helsinki, and approved by Ethics Committee at Wroclaw Medical University, Wroclaw, Poland (study protocol: STM C230.018.34; approval number: 254/2018; date of approval: 19 July 2018).

Informed Consent Statement: Informed consent was obtained from all subjects involved in the study.

Data Availability Statement: The data presented in this study are available on request from the corresponding author.

Conflicts of Interest: The authors declare no conflict of interest. The funders had no role in the design of the study; in the collection, analyses, or interpretation of data; in the writing of the manuscript, or in the decision to publish the results.

\section{References}

1. Misiak, B.; Stramecki, F.; Gawęda, Ł.; Prochwicz, K.; Sąsiadek, M.M.; Moustafa, A.A.; Frydecka, D. Interactions Between Variation in Candidate Genes and Environmental Factors in the Etiology of Schizophrenia and Bipolar Disorder: A Systematic Review. Mol. Neurobiol. 2018, 55, 5075-5100. [CrossRef] [PubMed]

2. Matheson, S.L.; Shepherd, A.M.; Pinchbeck, R.M.; Laurens, K.R.; Carr, V.J. Childhood adversity in schizophrenia: A systematic meta-analysis. Psychol. Med. 2013, 43, 225-238. [CrossRef]

3. Dauvermann, M.R.; Donohoe, G. The role of childhood trauma in cognitive performance in schizophrenia and bipolar disorder-A systematic review. Schizophr. Res. Cogn. 2019, 16, 1-11. [CrossRef]

4. Gawęda, Ł.; Pionke, R.; Krężołek, M.; Prochwicz, K.; Kłosowska, J.; Frydecka, D.; Misiak, B.; Kotowicz, K.; Samochowiec, A.; Mak, M.; et al. Self-disturbances, cognitive biases and insecure attachment as mechanisms of the relationship between traumatic life events and psychotic-like experiences in non-clinical adults-A path analysis. Psychiatry Res. 2018, 259, 571-578. [CrossRef]

5. Gawęda, Ł.; Pionke, R.; Arciszewska, A.; Prochwicz, K.; Frydecka, D.; Misiak, B.; Cechnicki, A.; Cicero, D.C.; Nelson, B. A combination of self-disturbances and psychotic-like experiences. A cluster analysis study on a non-clinical sample in Poland. Psychiatry Res. 2019, 273, 394-401. [CrossRef]

6. Turley, D.; Drake, R.; Killackey, E.; Yung, A.R. Perceived stress and psychosis: The effect of perceived stress on psychotic-like experiences in a community sample of adolescents. Early Interv. Psychiatry 2019, 13, 1465-1469. [CrossRef]

7. Bonoldi, I.; Simeone, E.; Rocchetti, M.; Codjoe, L.; Rossi, G.; Gambi, F.; Balottin, U.; Caverzasi, E.; Politi, P.; Fusar-Poli, P. Prevalence of self-reported childhood abuse in psychosis: A meta-analysis of retrospective studies. Psychiatry Res. 2013, $210,8-15$. [CrossRef]

8. Sideli, L.; Murray, R.M.; Schimmenti, A.; Corso, M.; La Barbera, D.; Trotta, A.; Fisher, H.L. Childhood adversity and psychosis: A systematic review of bio-psycho-social mediators and moderators. Psychol. Med. 2020, 50, 1761-1782. [CrossRef]

9. Beards, S.; Gayer-Anderson, C.; Borges, S.; Dewey, M.E.; Fisher, H.L.; Morgan, C. Life events and psychosis: A review and meta-analysis. Schizophr. Bull. 2013, 39, 740-747. [CrossRef]

10. Van Os, J.; Linscott, R.J.; Myin-Germeys, I.; Delespaul, P.; Krabbendam, L. A systematic review and meta-analysis of the psychosis continuum: Evidence for a psychosis proneness-persistence-impairment model of psychotic disorder. Psychol. Med. 2009, 39, 179-195. [CrossRef]

11. Sideli, L.; Murray, R.M.; Schimmenti, A.; Corso, M.; La Barbera, D.; Trotta, A.; Fisher, H.L. A systematic review of biopsychosocial mediators and moderators of the association between childhood adversity and psychosis. Res. Psychother. Psychopathol. Process Outcome 2018, 11, 1761-1782. 
12. Gawęda, Ł.; Prochwicz, K.; Adamczyk, P.; Frydecka, D.; Misiak, B.; Kotowicz, K.; Szczepanowski, R.; Florkowski, M.; Nelson, B. The role of self-disturbances and cognitive biases in the relationship between traumatic life events and psychosis proneness in a non-clinical sample. Schizophr. Res. 2018, 193, 218-224. [CrossRef]

13. Nolan, E.; Murphy, S.; O’Neill, T.; Houston, J.; Murphy, J.; Shevlin, M. Prevalence of psychotic-like experiences and associated distress in adolescent community, sexual-trauma and clinical samples. Psychosis 2018, 10, 251-262. [CrossRef]

14. Lee, K.W.; Chan, K.W.; Chang, W.C.; Lee, E.H.M.; Hui, C.L.M.; Chen, E.Y.H. A systematic review on definitions and assessments of psychotic-like experiences. Early Interv. Psychiatry 2016, 10, 3-16. [CrossRef]

15. Healy, C.; Cannon, M. Psychotic-like experiences in the general population. Risk Factors Psychos. 2020, 119-141. [CrossRef]

16. Kelleher, I.; Cannon, M. Psychotic-like experiences in the general population: Characterizing a high-risk group for psychosis. Psychol. Med. 2011, 41, 1-6. [CrossRef] [PubMed]

17. Yung, A.R.; Nelson, B.; Baker, K.; Buckby, J.A.; Baksheev, G.; Cosgrave, E.M. Psychotic-like experiences in a community sample of adolescents: Implications for the continuum model of psychosis and prediction of schizophrenia. Aust. N. Z. J. Psychiatry 2009, 43, 118-128. [CrossRef] [PubMed]

18. Van Os, J.; Reininghaus, U. Psychosis as a transdiagnostic and extended phenotype in the general population. World Psychiatry 2016, 15, 118-124. [CrossRef] [PubMed]

19. Linscott, R.J.; Van Os, J. An updated and conservative systematic review and meta-analysis of epidemiological evidence on psychotic experiences in children and adults: On the pathway from proneness to persistence to dimensional expression across mental disorders. Psychol. Med. 2013, 43, 1133-1149. [CrossRef] [PubMed]

20. Lu, D.; Wang, W.; Qiu, X.; Qing, Z.; Lin, X.; Liu, F.; Wu, W.; Yang, X.; Otake, Y.; Luo, X.; et al. The prevalence of confirmed childhood trauma and its' impact on psychotic-like experiences in a sample of Chinese adolescents. Psychiatry Res. 2020, 287, 112897. [CrossRef]

21. Sun, M.; Xue, Z.; Zhang, W.; Guo, R.; Hu, A.; Li, Y.; Mwansisya, T.E.; Zhou, L.; Liu, C.; Chen, X.; et al. Psychotic-like experiences, trauma and related risk factors among "left-behind" children in China. Schizophr. Res. 2017, 181, 43-48. [CrossRef]

22. Sun, M.; Zhang, W.; Guo, R.; Hu, A.; Li, Y.; Mwansisya, T.E.; Zhou, L.; Liu, C.; Chen, X.; Tao, H.; et al. Psychotic-like experiences and correlation with childhood trauma and other socio-demographic factors: A cross-sectional survey in adolescence and early adulthood in China. Psychiatry Res. 2017, 255, 272-277. [CrossRef]

23. Smith, S.M.; Vale, W.W. The role of the hypothalamic-pituitary-adrenal axis in neuroendocrine responses to stress. Dialogues Clin. Neurosci. 2006, 8, 383-395. [CrossRef] [PubMed]

24. Tsigos, C.; Chrousos, G.P. Hypothalamic-pituitary-adrenal axis, neuroendocrine factors and stress. J. Psychosom. Res. 2002, 53, 865-871. [CrossRef]

25. Shah, J.L.; Malla, A.K. Much ado about much: Stress, dynamic biomarkers and HPA axis dysregulation along the trajectory to psychosis. Schizophr. Res. 2015, 162, 253-260. [CrossRef]

26. Thompson, K.N.; Phillips, L.J.; Komesaroff, P.; Yuen, H.P.; Wood, S.J.; Pantelis, C.; Velakoulis, D.; Yung, A.R.; McGorry, P.D. Stress and HPA-axis functioning in young people at ultra high risk for psychosis. J. Psychiatr. Res. 2007, 41, 561-569. [CrossRef]

27. Binder, E.B. The role of FKBP5, a co-chaperone of the glucocorticoid receptor in the pathogenesis and therapy of affective and anxiety disorders. Psychoneuroendocrinology 2009, 34, S186-S195. [CrossRef] [PubMed]

28. Wochnik, G.M.; Rüegg, J.; Abel, G.A.; Schmidt, U.; Holsboer, F.; Rein, T. FK506-binding proteins 51 and 52 differentially regulate dynein interaction and nuclear translocation of the glucocorticoid receptor in mammalian cells. J. Biol. Chem. 2005, 280, 4609-4616. [CrossRef] [PubMed]

29. Scammell, J.G.; Denny, W.B.; Valentine, D.L.; Smith, D.F. Overexpression of the FK506-Binding Immunophilin FKBP51 Is the Common Cause of Glucocorticoid Resistance in Three New World Primates. Gen. Comp. Endocrinol. 2001, 124, 152-165. [CrossRef] [PubMed]

30. Sinclair, D.; Fillman, S.G.; Webster, M.J.; Weickert, C.S. Dysregulation of glucocorticoid receptor co-factors FKBP5, BAG1 and PTGES3 in prefrontal cortex in psychotic illness. Sci. Rep. 2013, 3, 3539. [CrossRef] [PubMed]

31. Darby, M.M.; Yolken, R.H.; Sabunciyan, S. Consistently altered expression of gene sets in postmortem brains of individuals with major psychiatric disorders. Transl. Psychiatry 2016, 6, e890. [CrossRef]

32. Girshkin, L.; Matheson, S.L.; Shepherd, A.M.; Green, M.J. Morning cortisol levels in schizophrenia and bipolar disorder: A meta-analysis. Psychoneuroendocrinology 2014, 49, 187-206. [CrossRef]

33. Hubbard, D.B.; Miller, B.J. Meta-analysis of blood cortisol levels in individuals with first-episode psychosis. Psychoneuroendocrinology 2019, 104, 269-275. [CrossRef]

34. Berger, M.; Kraeuter, A.K.; Romanik, D.; Malouf, P.; Amminger, G.P.; Sarnyai, Z. Cortisol awakening response in patients with psychosis: Systematic review and meta-analysis. Neurosci. Biobehav. Rev. 2016, 68, 157-166. [CrossRef]

35. Ciufolini, S.; Dazzan, P.; Kempton, M.J.; Pariante, C.; Mondelli, V. HPA axis response to social stress is attenuated in schizophrenia but normal in depression: Evidence from a meta-analysis of existing studies. Neurosci. Biobehav. Rev. 2014, 47, 359-368. [CrossRef]

36. Chaumette, B.; Kebir, O.; Mam-Lam-Fook, C.; Morvan, Y.; Bourgin, J.; Godsil, B.P.; Plaze, M.; Gaillard, R.; Jay, T.M.; Krebs, M.O. Salivary cortisol in early psychosis: New findings and meta-analysis. Psychoneuroendocrinology 2016, 63, 262-270. [CrossRef]

37. Borges, S.; Gayer-Anderson, C.; Mondelli, V. A systematic review of the activity of the hypothalamic-pituitary-adrenal axis in first episode psychosis. Psychoneuroendocrinology 2013, 38, 603-611. [CrossRef] 
38. Cristóbal-Narváez, P.; Sheinbaum, T.; Rosa, A.; de Castro-Catala, M.; Domínguez-Martínez, T.; Kwapil, T.R.; Barrantes-Vidal, N. Interaction of both positive and negative daily-life experiences with FKBP5 haplotype on psychosis risk. Eur. Psychiatry 2020, 63. [CrossRef]

39. Mihaljevic, M.; Zeljic, K.; Soldatovic, I.; Andric, S.; Mirjanic, T.; Richards, A.; Mantripragada, K.; Pekmezovic, T.; Novakovic, I.; Maric, N.P. The emerging role of the FKBP5 gene polymorphisms in vulnerability-stress model of schizophrenia: Further evidence from a Serbian population. Eur. Arch. Psychiatry Clin. Neurosci. 2017, 267, 527-539. [CrossRef] [PubMed]

40. Ajnakina, O.; Borges, S.; Di Forti, M.; Patel, Y.; Xu, X.; Green, P.; Stilo, S.A.; Kolliakou, A.; Sood, P.; Marques, T.R.; et al. Role of Environmental Confounding in the Association between FKBP5 and First-Episode Psychosis. Front. Psychiatry 2014, 5. [CrossRef] [PubMed]

41. Cristóbal-Narváez, P.; Sheinbaum, T.; Ballespí, S.; Mitjavila, M.; Myin-Germeys, I.; Kwapil, T.R.; Barrantes-Vidal, N. Impact of adverse childhood experiences on psychotic-like symptoms and stress reactivity in daily life in nonclinical young adults. PLoS ONE 2016, 11, e0153557. [CrossRef]

42. de Castro-Catala, M.; Peña, E.; Kwapil, T.R.; Papiol, S.; Sheinbaum, T.; Cristóbal-Narváez, P.; Ballespí, S.; Barrantes-Vidal, N.; Rosa, A. Interaction between FKBP5 gene and childhood trauma on psychosis, depression and anxiety symptoms in a non-clinical sample. Psychoneuroendocrinology 2017, 85, 200-209. [CrossRef] [PubMed]

43. Cristóbal-Narváez, P.; Sheinbaum, T.; Myin-Germeys, I.; Kwapil, T.R.; de Castro-Catala, M.; Domínguez-Martínez, T.; Racioppi, A.; Monsonet, M.; Hinojosa-Marqués, L.; van Winkel, R.; et al. The role of stress-regulation genes in moderating the association of stress and daily-life psychotic experiences. Acta Psychiatr. Scand. 2017, 136, 389-399. [CrossRef] [PubMed]

44. Alemany, S.; Moya, J.; Ibáñez, M.I.; Villa, H.; Mezquita, L.; Ortet, G.; Gastó, C.; Fañanás, L.; Arias, B. Research Letter: Childhood trauma and the rs1360780 SNP of FKBP5 gene in psychosis: A replication in two general population samples. Psychol. Med. 2016, 46, 221-223. [CrossRef] [PubMed]

45. Cristóbal-Narváez, P.; Sheinbaum, T.; Rosa, A.; Ballespí, S.; De Castro-Catala, M.; Peña, E.; Kwapil, T.R.; Barrantes-Vidal, N. The interaction between childhood bullying and the FKBP5 gene on psychotic-like experiences and stress reactivity in real life. PLoS ONE 2016, 11, e0158809. [CrossRef]

46. Womersley, J.S.; Martin, L.I.; van der Merwe, L.; Seedat, S.; Hemmings, S.M.J. Hypothalamic-pituitary-adrenal axis variants and childhood trauma influence anxiety sensitivity in South African adolescents. Metab. Brain Dis. 2018, 33, 601-613. [CrossRef]

47. Mahon, P.B.; Zandi, P.P.; Potash, J.B.; Nestadt, G.; Wand, G.S. Genetic association of FKBP5 and CRHR1 with cortisol response to acute psychosocial stress in healthy adults. Psychopharmacology 2013, 227, 231-241. [CrossRef]

48. Siepel, A.; Bejerano, G.; Pedersen, J.S.; Hinrichs, A.S.; Hou, M.; Rosenbloom, K.; Clawson, H.; Spieth, J.; Hillier, L.D.W.; Richards, S.; et al. Evolutionarily conserved elements in vertebrate, insect, worm, and yeast genomes. Genome Res. 2005, 15, 1034-1050. [CrossRef]

49. King, D.C.; Taylor, J.; Elnitski, L.; Chiaromonte, F.; Miller, W.; Hardison, R.C. Evaluation of regulatory potential and conservation scores for detecting cis-regulatory modules in aligned mammalian genome sequences. Genome Res. 2005, 15, 1051-1060. [CrossRef]

50. Collip, D.; Myin-Germeys, I.; Wichers, M.; Jacobs, N.; Derom, C.; Thiery, E.; Lataster, T.; Simons, C.; Delespaul, P.; Marcelis, M.; et al. FKBP5 as a possible moderator of the psychosis-inducing effects of childhood trauma. Br. J. Psychiatry 2013, 202, 261-268. [CrossRef]

51. Nijenhuis, E.R.S.; Van der Hart, O.; Kruger, K. The psychometric characteristics of the traumatic experiences checklist (TEC): First findings among psychiatric outpatients. Clin. Psychol. Psychother. 2002, 9, 200-210. [CrossRef]

52. Ising, H.K.; Veling, W.; Loewy, R.L.; Rietveld, M.W.; Rietdijk, J.; Dragt, S.; Klaassen, R.M.C.; Nieman, D.H.; Wunderink, L.; Linszen, D.H.; et al. The validity of the 16-item version of the prodromal questionnaire (PQ-16) to screen for ultra high risk of developing psychosis in the general help-seeking population. Schizophr. Bull. 2012, 38, 1288-1296. [CrossRef] [PubMed]

53. Frydecka, D.; Kotowicz, K.; Gawęda, Ł.; Prochwicz, K.; Kłosowska, J.; Rymaszewska, J.; Samochowiec, A.; Samochowiec, J.; Podwalski, P.; Pawlak-Adamska, E.; et al. Effects of interactions between variation in dopaminergic genes, traumatic life events, and anomalous self-experiences on psychosis proneness: Results from a cross-sectional study in a nonclinical sample. Eur. Psychiatry 2020, 63, 1-17. [CrossRef]

54. Cozier, Y.C.; Palmer, J.R.; Rosenberg, L. Comparison of methods for collection of DNA samples by mail in the black women's health study. Ann. Epidemiol. 2004, 14, 117-122. [CrossRef]

55. Lefort, M.-C.; Boyer, S.; Barun, A.; Emami Khoyi, A.; Ridden, J.; Smith, V.; Sprague, R.; Waterhouse, B.; Cruickshank, R. Blood, sweat and tears: Non-invasive vs. non-disruptive DNA sampling for experimental biology. PeerJ 2014. [CrossRef]

56. Millikan, R. The changing face of epidemiology in the genomics era. Epidemiology 2002, 13, 472-480. [CrossRef] [PubMed]

57. Bonin, A.; Bellemain, E.; Eidesen, P.B.; Pompanon, F.; Brochmann, C.; Taberlet, P. How to track and assess genotyping errors in population genetics studies. Mol. Ecol. 2004, 13, 3261-3273. [CrossRef]

58. Binder, E.B.; Salyakina, D.; Lichtner, P.; Wochnik, G.M.; Ising, M.; Pütz, B.; Papiol, S.; Seaman, S.; Lucae, S.; Kohli, M.A.; et al Polymorphisms in FKBP5 are associated with increased recurrence of depressive episodes and rapid response to antidepressant treatment. Nat. Genet. 2004, 36, 1319-1325. [CrossRef]

59. Luijk, M.P.C.M.; Velders, F.P.; Tharner, A.; van IJzendoorn, M.H.; Bakermans-Kranenburg, M.J.; Jaddoe, V.W.V.; Hofman, A.; Verhulst, F.C.; Tiemeier, H. FKBP5 and resistant attachment predict cortisol reactivity in infants: Gene-environment interaction. Psychoneuroendocrinology 2010, 35, 1454-1461. [CrossRef] 
60. Zannas, A.S.; Binder, E.B. Gene-environment interactions at the FKBP5 locus: Sensitive periods, mechanisms and pleiotropism. Genes, Brain Behav. 2014, 13, 25-37. [CrossRef]

61. Yaylaci, F.T.; Cicchetti, D.; Rogosch, F.A.; Bulut, O.; Hetzel, S.R. The interactive effects of child maltreatment and the FK506 binding protein 5 gene (FKBP5) on dissociative symptoms in adolescence. Dev. Psychopathol. 2017, 29, 1105-1117. [CrossRef]

62. Longden, E.; Branitsky, A.; Moskowitz, A.; Berry, K.; Bucci, S.; Varese, F. The relationship between dissociation and symptoms of psychosis: A meta-analysis. Schizophr. Bull. 2020, 46. [CrossRef]

63. Anglin, D.M.; Espinosa, A.; Barada, B.; Tarazi, R.; Feng, A.; Tayler, R.; Allicock, N.M.; Pandit, S. Comparing the Role of Aberrant Salience and Dissociation in the Relation between Cumulative Traumatic Life Events and Psychotic-Like Experiences in a Multi-Ethnic Sample. J. Clin. Med. 2019, 8, 1223. [CrossRef]

64. Mitjans, M.; Catalán, R.; Vázquez, M.; González-Rodríguez, A.; Penadés, R.; Pons, A.; Massana, G.; Munro, J.; Arranz, M.J.; Arias, B. Hypothalamic-pituitary-adrenal system, neurotrophic factors and clozapine response: Association with FKBP5 and NTRK2 genes. Pharmacogenet. Genom. 2015, 25, 274-277. [CrossRef] [PubMed]

65. Zannas, A.S.; Wiechmann, T.; Gassen, N.C.; Binder, E.B. Gene-Stress-Epigenetic Regulation of FKBP5: Clinical and Translational Implications. Neuropsychopharmacology 2016, 41, 261-274. [CrossRef]

66. Schmidt, M.V.; Paez-Pereda, M.; Holsboer, F.; Hausch, F. The Prospect of FKBP51 as a Drug Target. ChemMedChem 2012, 7, 1351-1359. [CrossRef] [PubMed]

67. Amad, A.; Ramoz, N.; Peyre, H.; Thomas, P.; Gorwood, P. FKBP5 gene variants and borderline personality disorder. J. Affect. Disord. 2019, 248, 26-28. [CrossRef]

68. de Castro-Catala, M.; van Nierop, M.; Barrantes-Vidal, N.; Cristóbal-Narváez, P.; Sheinbaum, T.; Kwapil, T.R.; Peña, E.; Jacobs, N.; Derom, C.; Thiery, E.; et al. Childhood trauma, BDNF Val66Met and subclinical psychotic experiences. Attempt at replication in two independent samples. J. Psychiatr. Res. 2016, 83, 121-129. [CrossRef]

69. Alemany, S.; Arias, B.; Aguilera, M.; Villa, H.; Moya, J.; Ibáñez, M.I.; Vossen, H.; Gastó, C.; Ortet, G.; Fañanás, L. Childhood abuse, the BDNF-Val66Met polymorphism and adult psychotic-like experiences. Br. J. Psychiatry 2011, 199, 38-42. [CrossRef]

70. Fisher, H.L.; Craig, T.K.; Fearon, P.; Morgan, K.; Dazzan, P.; Lappin, J.; Hutchinson, G.; Doody, G.A.; Jones, P.B.; McGuffin, P.; et al. Reliability and comparability of psychosis patients' retrospective reports of childhood abuse. Schizophr. Bull. 2011, 37, 546-553. [CrossRef]

71. Liu, J.; Mahendran, R.; Chong, S.A.; Subramaniam, M. Elucidating the Impact of Childhood, Adulthood, and Cumulative Lifetime Trauma Exposure on Psychiatric Symptoms in Early Schizophrenia Spectrum Disorders. J. Trauma. Stress 2020, 34, 137-148. [CrossRef] [PubMed] 